Bidik: Jurnal Pengabdian kepada Masyarakat | Vol. 1 No. 2 April 2021

DOI: https://doi.org/10.31849/bidik.v1i2.6405

\title{
Pendampingan Pemasaran Potensi Pariwisata Pagaralam Untuk Kawasan Timur Tengah
}

\author{
Muhammad Walidin*, Isnaini Rahmawati**, Yuli Santiani*** \\ Prodi Bahasa dan Sastra Arab, Fakultas Adab dan Humaniora \\ Universitas Islam Negeri Raden Fatah Palembang \\ *Email : muhammadwalidin uin@,radenfatah.ac.id
}

\begin{abstract}
Community Service with the theme Marketing the Potential Tourism of Pagaralam for the Middle East people is aimed to advocate the public to be aware of tourism and to become independent tourism ambassadors for their own region. The team from the Arabic Language and Literature Study Program collaborated with the community represented by the academic community of the Al-Azhar Islamic Boarding School to develop a social media-based tourism marketing pattern (Youtube). This process begins with brainstorming, composing a narrative text, translating text into Arabic, taking pictures and video, editing, and downloading video to Youtube. The result of the program is the appearance of a short video in Arabic as a form of marketing the potential tourism of Pagaralam to the Middle East people.
\end{abstract}

Keywords: Marketing, tourism, Middle East

\begin{abstract}
Abstrak
Pengabdian Kepada Masyarakat dengan tema Pendampingan Pemasaran Potensi Pariwisata Pagaralam untuk Kawasan Timur Tengah bertujuan untuk mengadvokasi masyarakat agar sadar wisata dan bisa menjadi duta wisata mandiri bagi daerahnya. Tim dari Prodi Bahasa dan Sastra Arab berkolaborasi dengan masyarakat yang diwakili oleh civitas akademika Pondok Pesantren al-Azhar menyusun pola pemasaran pariwisata berbasis media sosial (Youtube). Proses ini diawali dengan curah gagasan, menyusun narasi, menerjemahkan ke dalam bahasa Arab, pengambilan gambar, penyuntingan, dan pengunduhan. Youtube. Adapun hasil dari program adalah tampilnya video pendek berbahasa Arab sebagai bentuk pemasaran potensi pariwisata Pagaralam di wilayah Timur Tengah.
\end{abstract}

Kata kunci: pemasaran; pariwisata; Timur Tengah

\section{Pendahuluan}

Perguruan tinggi di Indonesia memiliki keunikan tersendiri. Di samping sebagai pusat pendidikan dan penelitian, perguruan tinggi di Indonesia juga harus sensitif dengan kebutuhan masyarakat dengan programnya yang terbaik, yaitu pengabdian kepada masyarakat. Hal ini menjadikan perguruan tinggi di Indonesia tidak berada di puncak menara gading yang abai kepada masyarakat, tetapi menjadi penggerak bagi dinamisasi kehidupan masyarakat.

Program studi bahasa dan sastra Arab sebagai ujung tombak dari satuan pendidikan di Universitas Islam Negeri Raden Fatah Palembang juga aktif melakukan kegiatan Pengabdian Masyarakat. Sesuai dengan Road Map Pengabdian Masyarakat Prodi Bahasa dan Sastra Arab 
(selanjutnya disingkat BSA), kali ini dosen dan mahasiswa membidik program pendampingan pemasaran potensi pariwisata di Kota Pagaralama Sumatera Selatan sebagai objek utama.

Kota Pagaralam sudah menjadi primadona pariwisata Sumatera Selatan sejak dahulu kala. Keberadaan gunung dempo dengan perkebunan tehnya telah exis sejak penjajahan belanda (dibangun sejak 2 Mei 1929 oleh sebuah perusahaan Belanda, NV Lanbouw Maata Chapij). Hamparan kebun teh yang luas dengan latar belakang gunung dempo serta hawa sejuk di kawasan ini telah menjadi perhatian utama masyarakat Sumatera Selatan dan sekitarnya. Saat ini pembangunan ekonomi kreatif (pariwisata dan turunannya) perlahan mengambil porsi yang besar di samping pertanian sebagai andalan utama. Berbagai titik pariwisata baru bermunculan, baik yang natural maupun yang millenial. Diversifikasi ekonomi kini berjalan baik di kota Pagaralam.

Pembangunan kota Pagaralam dalam berbagai segi ditopang pula oleh kebijakan proaktif pemerintah kota dan pemerintah provinsi. Sebuah lapangan terbang madya bernama Bandara Atung Bungsu telah berdiri sejak 28 Februari 2013. Bandara ini dipersiapkan untuk menyambut insan pariwisata nasional maupun internasional, bahkan juga investor yang berminat untuk menanamkan sahamnya terutama di bidang pertanian dan pariwisata.

Dengan fasilitas yang telah terbangun sempurna, Prodi BSA ingin berkontribusi bagi pariwisata Pagaralam dengan cara menginternasonalisasikan potensi wisata ke 27 negara-negara yang menggunakan bahasa Arab sebagai bahasa utama. Promosi ini bisa mengambil media sosial sebagai perantaranya. Media sosial seperti Youtube merupakan media gratis dan digandrungi pelaku wisata karena aksesnya yang mudah dan murah.

Untuk tujuan di atas, dosen dan mahasiwa Prodi BSA akan melakukan pendampingan kepada masyarakat di kota Pagaralam. Sebuah Yayasan yang menaungi Pesantren al-Azhar menjadi tempat yang cocok untuk mendiseminasikan ide ini. Para guru dan siswa Bahasa Arab akan dibimbing menentukan objek, menyusun naskah berbahasa Arab, membuat video, mengedit video, dan menguploadnya ke saluran Youtube. Cara ini diyakini dapat menstimulasi pengembangan promosi serupa sehingga lambat laun seluruh potensi pariwisata di Kota Pagaralam semuaya telah ditranskripsi ke dalam video (Youtube). Harapan akhirnya, potensi pariwisata kota Pagaralam bisa terkenal di negara-negara Arab dan bisa mengundang kedatangan turis internasional. Efeknya di kemudian hari, tentu ekonomi kreatif masyarakat kota Pagaralam akan semakin bertumbuh dan berkembang.

\section{Pedekatan Pelaksanaan Program}

Pendekatan yang digunakan dalam PkM ini adalah PRA (Participatoru Rural Appraisal). Sebuah metodologi yang digunakan untuk proses pembangunan masyarakat secara interaktif. Metode ini berangkat dari pola pembelajaran dari masyarakat, dengan masyarakat, dan oleh masyarakat.

Sebagaimana telah diterangkan pada bab pendahuluan bahwa kota Pagaralam memiliki potensi wisata alam yang luar biasa. Spot wisata tersebut mencakup wisata pegunungan, hamparan kebun teh, air terjun, situs megalitikum, dan desa wisata heritage: Pelang Kenidai. Potensi-potensi ini diungkapkan oleh Sekretaris Daerah Kota Pagaralam saat peneliti melakukan kunjungan dalam rangka izin untuk program pengabdian kepada masyarakat sekaligus menginventarisr kontribusi apa yang bisa diberikan oleh civitas akademika Prodi BSA

Prodi Bahasa dan Sastra Arab UIN Raden Fatah menginisiasi untuk berkolaborasi dengan civitas akademika Pondok Pesantren al-Azhar Pagaralam. Lembaga pendidikan ini juga memiliki alur pembelajaran Bahasa Arab sebagaimana menjadi konsentrasi prodi Bahasa dan Sastra Arab UIN Raden Fatah.

Pada sesi pertama, dilakukan kuliah umum tentang potensi pariwisata Pagaralam yang sangat besar di hadapan para guru dan santri. Kalaulah potensi tersebut telah dinikmati oleh turis dalam 
negeri, para santri bisa berkontribusi untuk mengundang wisatawan asal Timur Tengah untuk datang ke Pagaralam, baik untuk vakansi ataupun investasi. Kemampuan para santri dalam komunikasi bahasa Arab adalah modal besar bagi pemasaran ini.

Setelah kuliah umum, dipilihlah beberapa santri yang bagus dalam penguasaan bahasa Arab. Mereka ditemani oleh guru bahasa Arab. Kepada mereka, dilakukan brainstorming tentang wisata apa yang akan menjadi prioritas pemasaran yang bisa digunakan sebagai prototype. Langkah selanjutnya adalah penulisan narasi dan penerjemahan ke dalam bahasa Arab. Tahap berikutnya adalah Shooting di lokasi wisata. Dilanjutkan dengan editing video dan diakhir dengan uploading di kanal youtube.

Dengan tampilnya video spot pariwisata di kanal Youtube tersebut, masyarakat internasional dapat mengakses potensi pariwisata Pagaralam. Adapun evaluasinya adalah dengan menganalisis respon dalam komentar pemirsa. Namun, hal ini tentu memerlukan waktu tambahan.

\section{Pelaksanaan Program}

Program Pengabdian kepada Masyarakat dengan tema Pendampingan Pemasaran Potensi Pariwisata Kota Pagaralam Sumatera Selatan ini dilakukan pada periode semester ganjil 2020/2021, tepatnya pada tanggal 14-15 Desember 2020. Kegiatan ini dilakukan di Pondok Pesantren al-Azhar di bawah naungan Yayasan Pendidikan Islam Pagaralam Kota Pagaralam Sumatera Selatan.

Sebagai pendamping, hadir di lokasi secara fisik adalah Muhammad Walidin, M.Hum., Isnaini Rahmawati, M.Hum., dan seorang mahasiswa prodi BSA, Yuli Santiani (angkatan 2017). Para dosen dan mahasiswa prodi BSA di atas berkolaborasi dengan guru dan siswa terpilih untuk mengeksekusi pendampingan pemasaran pariwisata. Hadir dari Pondok Pesantren al-Azhar adalah Ustazah Yesi Pramaswari dan Ustazah Fella Indah Marsela. Keduanya adalah guru bahasa Arab dan 2 orang santri bernama Siti Khotijah dan Bulan Ramadhani.

Sebagaimana diugkapkan di atas, bahwa kegiatan ini sebelumnya didahului dengan anjangsana civitas akademika Prodi BSA ke kantor walikota Pagaralam. Tim disambut oleh Sekretaris Daerah Kota Pagaralam, Drs. Samsul Bahri Burlian, MM. Dalam sambutannya, Pejabat Sekda menerangkan potensi geografis dan demografis kota Pagaralam. Kepada tim pengabdian, sekda memberikan kebebasan untuk mengeksplore kota Pagaralam berdasarkan potensi yang ada.

Secara geografis Kota Pagar Alam berada pada posisi 4o Lintang Selatan (LS) dan 103,15o Bujur Timur (BT) , 030 59'08” - 040 15' 45” Lintang Selatan dan 1030 07'00” - 1030 27' 26” Bujur Timur dengan luas wilayah $63.366 \mathrm{Ha}(633.66 \mathrm{Km} 2$ ) dan terletak sekitar $298 \mathrm{Km}$ dari Palembang serta berjarak $60 \mathrm{Km}$ di sebelah barat daya dari ibukota kabupaten Lahat. Kota Pagar Alam merupakan daerah yang berbukit dengan ketinggian 400-3.400 diatas permukaan laut (dpl). Kondisi topografi bervariasi dari 0 sampai 15 derajat, sampai kelerengan 45 derajat.

Secara Administratif, wilayah ini terbagi atas 5 Kecamatan yaitu Kecamatan Pagar Alam Selatan, Pagar Alam Utara, Dempo Selatan, Dempo Utara, dan Dempo Tengah, serta terdiri dari 35 Kelurahan dan 84 Dusun. Daerah yang berbatasan dengan wilayah Kota Pagar Alam mempunyai batas wilayah sebagai berikut : Sebelah Utara : Berbatasan dengan kecamatan Jarai, kabupaten Lahat. Sebelah Timur : Berbatasan dengan propinsi Bengkulu. Sebelah Selatan : Berbatasan dengan kecamatan Kota Agung, kabupaten Lahat. Sebelah Barat : Berbatasan dengan kecamatan Tanjung Sakti,kabupaten Lahat. (Sumber : BPS Kota Pagar Alam 2013). 


\section{Gambar 1. Tim bersama Sekretaris Daerah Kota Pagaralam dan pejabat terkait}

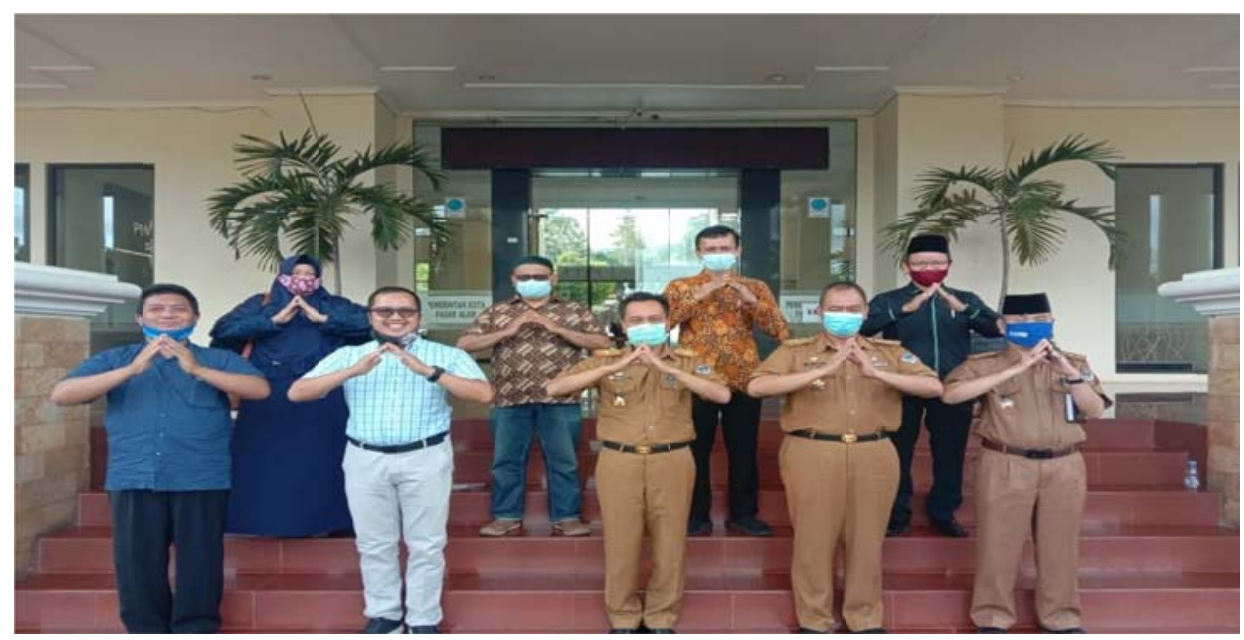

1. Sosialisasi Potensi Pariwisata

Di hadapan para 100 santriwati (santriwan saat itu memiliki kegiatan lain), tim Pengabdian kepada Masyarakat Prodi BSA menyampaikan kesempatan dan tantangan para santri untuk berkontribusi membangun kota Pagaralam dari aspek pariwisata dan pengembangan ekonomi kreatif. Kesempatan tersebut terbuka lebar bagi santriwan-santriwati Ponpes al-Azhar karena kompetensi mereka di bidang komunikasi bahasa Arab. Bila mereka terlibat aktif memasarkan potensi pariwisata Pagaralam dalam bahasa Arab ke 27 negara yang menjadikan bahasa Arab sebagai bahasa utama, maka peluang pengembangan diri dan ekonomi akan terbuka di hadapan mata.

Para santriwati terlihat antuisias mendengarkan paparan tim pengabdian. Mereka baru tersadarkan potensi keilmuwan mereka bisa digunakan secara praktis untuk membangun kota Pagaralam dengan cara pemasaran potensi pariwisata Pagaralam ke negara-negara yang menggunakan bahasa Arab sebagai bahasa utama.

Gambar 2. Santriwati antusias mendengarkan pemaparan potensi pariwisata 


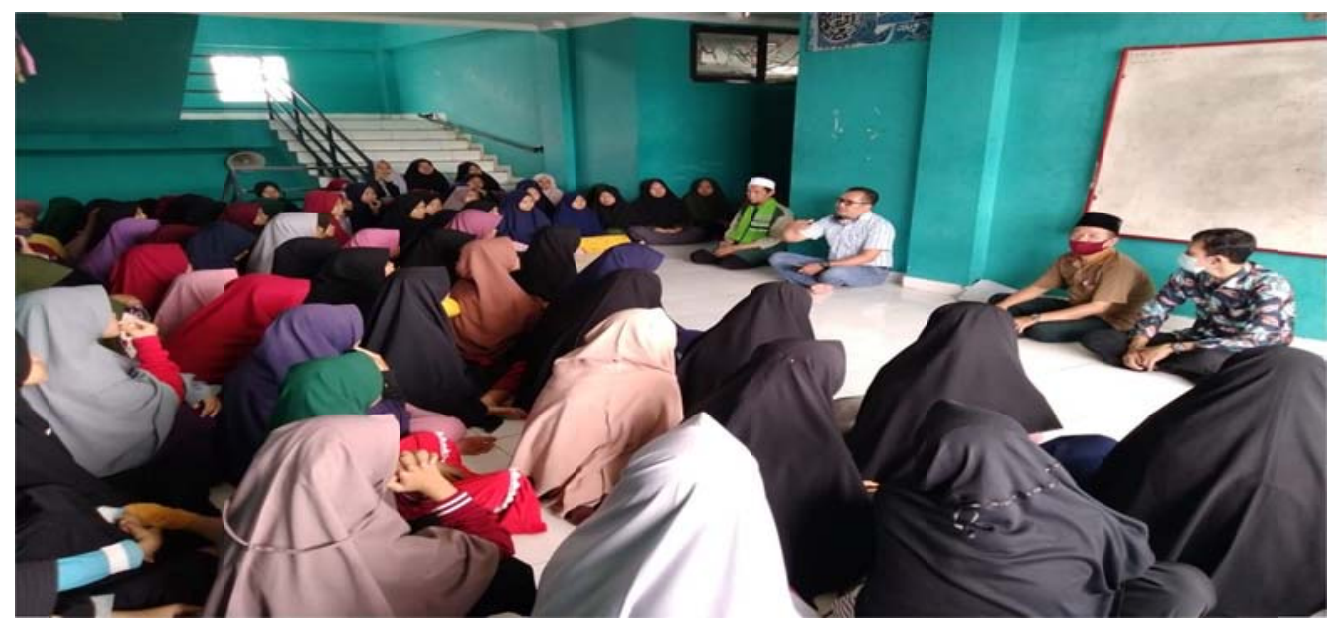

2. Proses Pemilihan Personalia dan objek wisata

Setelah diadakan kuliah umum, tim pengabdian mengundang santriwati yang tertarik untuk menjadi tim kolaborasi yang akan menyusun konsep pemasaran potensi pariwisata Pagaralam di wilayah Timur Tengah. Terdapat 2 santriwati dengan kemampuan penguasaan Bahasa Arab yang bagus yang dipilih di antara sekian kandidat. Mereka adalah Siti Khatijah dan Bulan Ramadhani. Kedua santriwati ini didampingi oleh pengajar bahasa Arab, yaitu Ustz. Yesi Pramaswari dan Ustz. Fella Indah Marsela.

Berdasarkan hasil brain storiming tim kolaborasi, dipilihlah tempat wisata alam perkebunan teh sebagai objek wisata yang akan dipasarkan.. Perkebunan teh dipilih karena merupakan ikon pariwisata Pagaralam. Semua wisatawan akan menuju tempat ini saat berwisata di Pagaralam. Adapun spot lain, seperti gunung dempo, air terjun, situs megalitikum merupakan pilihan kedua setelah perkebunan teh.

3. Proses Diskusi dan penyusunan narasi

Tim kolaborasi bergerak dengan pembagian tugas untuk menyusun narasi/teks berbahasa Indonesia. setelah dilakukan penyuntingan, maka sempurnalah teks berbahasa Indonesia sebagai berikut:

Secara geografis, Kota Pagar Alam terletak di kaki gunung dempo dengan ketinggian 3001100 meter di permukaan laut. Dengan kondisi geografis tersebut, tak heran bila kota Pagaralam berudara sejuk cenderung dingin. Pagaralam memiliki luas $633,7 \mathrm{~km}^{2}$. Pagaralam merupakan salah satu dari 12 kabupaten/kota di Sumatera Selatan yang dibentuk berdasarkan Undang-Undang Nomor 8 Tahun 2001.

Pagaralam dikarunia alam yang sejuk, udara yang segar, dan sinar matahari yang cerah. Selain itu, Pagaralam dikarunia kekayaan alam lainnya seperti tanah yang subur dan banyaknya air terjun. Berbagai keistimewaan ini menjadikan kota Pagaralam sebagai destinasi wisata andalan Sumatera Selatan.

Pagaralam memiliki ikon pariwisata yang sangat terkenal, yaitu Gunung Dempo. Di Kaki gunung ini terdapat kebun teh seluas 1.478 hektar. Kebun teh ini sudah ada sejak masa penjajahan belanda. Sebuah perusahaan kolonial Belanda bernama NV Lanbouw Maata Chapij mebangun perkebunan ini pada 2 Mei 1929. Pabrik kemudian dibangun kembali pada tahun 1951-1958 oleh perusahaan Belanda lain, Cultuur NV Soerabaya. 
Saat nasionalisasi perusahaan-perusahaan Belanda berlangsung hingga tahun 1963, perkebunan dikelola oleh Perusahaan Perkebunan Negara dengan nama yang berubah-ubah. Sejak tahun 1996, ia dikelola oleh BUMN bernama PTPN VII. Dengan luas perkebunan teh 1.478 hektar, PTPN VII rata-rata menghasilkan 40 ton teh pucuk basah setiap hari dan cenderung terus meningkat. Dalam setahun, produk teh Gunung Dempo rata-rata mencapai 14.000-17.000 ton teh pucuk basah atau setara 3.600-4.250 ton teh kering. Untuk melakukan proses ini, Pihak Perkebunan mempekerjakan sekitar 1000 orang pekerja.

Teh Gunung Dempo berkualitas baik karena menghadap sinar matahari pagi langsung. Sinar matahari selama pukul 07.00-10.00 membuat proses fotosintesis atau pembakaran zat hijau daun daun teh berlangsung sempurna. Tidak heran bila kualitas teh gunung dempo sangat istimewa dan 90 \% diperuntukkan pagi pasar ekspor, khususnya India dan Eropa. Bahkan banyak merek teh luar negeri juga menggunakan bahan baku dari teh gunung dempo.

Gunung Dempo menawarkan panorama pemandangan yang indah. Hamparan ladang petani dan hijaunya kebun teh menjadikan Gunung Dempo layaknya bidadari bagi pariwisata Sumatera Selatan. Bila berkunjung ke sini, berjalanlah melintasi perkebunan teh. Anda akan menemukan pemandangan nan indah khas pegunungan. Sepanjang mata memandang terhampar pemandangan hijau yang menyegarkan mata. Di sini pula peserta bisa menyaksikan para pekerja pemetik teh tengah memetik pucuk-pucuk daun teh.

Karena berada di ketinggian 1520 dpl, sesekali kaki Kaki Gunung Dempo tertutup kabut. Hal ini menambah suasana menjadi tambah menyenangkan karena jarangnya wisatawan kota menemukan kabut di kota tempat mereka tinggal.

Tepat di atas perkebunan, terdapat pendopo besar yang menandai puncak kebun teh. Untuk mencapai tempat ini, Anda harus melaluii jalan berkelok namun sangat baik kualitasnya. Hanya dibutuhkan waktu 15 menit untuk mencapai ke sana. Dari tempat ini pengunjung bisa melihat Kabupaten Pagaralam dari kejauhan dan melihat kebun teh dari dekat.

Memasuki akhir pekan, Kawasan Puncak Pagaralam ini akan diramaikan oleh para wisatawan. Mereka datang dari wilayah Sumatera Selatan atau juga dari luar daerah. Apalagi di sekitar kaki Gunung Dempo banyak terdapat fasilitas penginapan berupa hotel yang harga sewanya relatif terjangkau.

Selain itu, di kawasan ini juga ditemui penjual oleh-oleh khas Pagaralam, seperti kopi, teh, hingga figura senjata kudok. Mengunjungi Kebun Teh Pagaralam merupakan salah satu aktivitas liburan yang menyenangkan bersama keluarga. Selain bisa melihat pemandangan yang indah, suasana di kawasan ini juga sangat hening dan udaranya masih sangat sejuk.

Gunung Dempo yang berada di wilayah Kota Pagaralam merupakan puncak tertinggi di wilayah Sumatera Selatan. Kota ini berjarak sekitar 300 km dari pusat Kota Palembang. Bila menggunakan mobil dibutuhkan waktu tempu sekitar 8 jam. Bila menggunakan pesawat, hanya dibutuhkan 45 menit dari bandara Sultan Mahmud Badaruddin II Palembang.

Datanglah ke Pagaralam, Sumatera Selatan, Indonesia untuk merasakan indahnya alam karunia Tuhan. 


\section{Gambar 3. Penyusunan Narasi dan Penerjemahan}

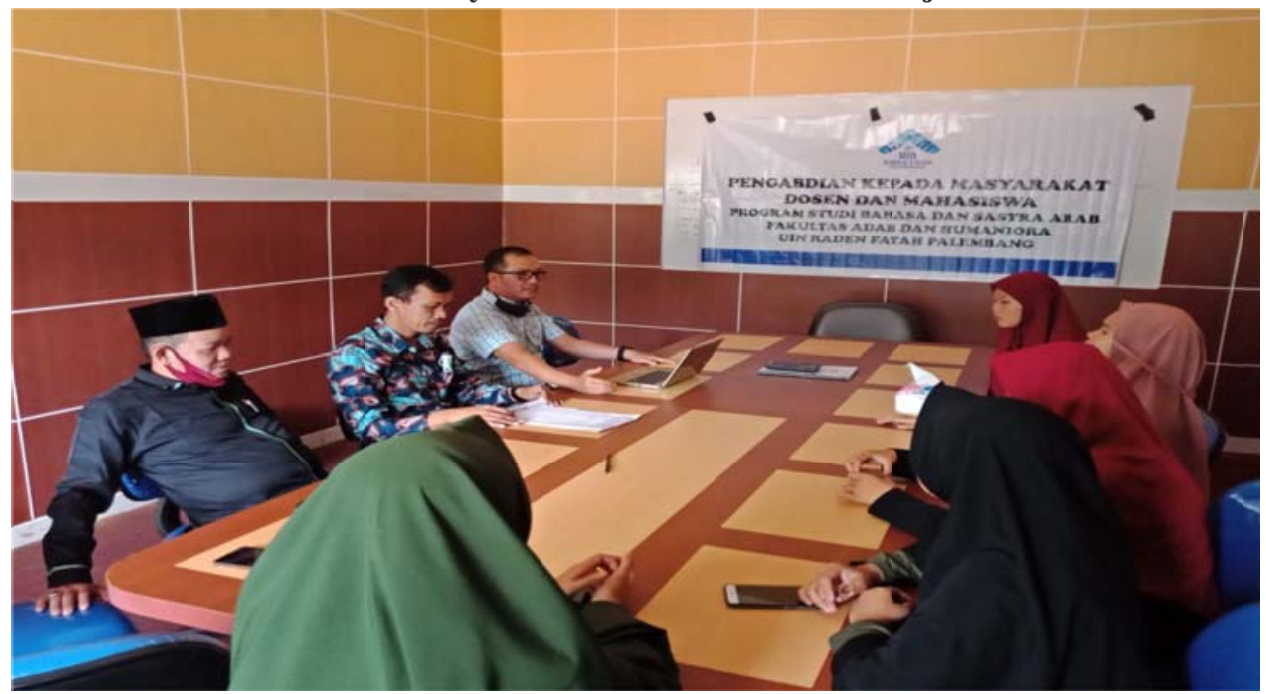

Setelah disepakati teks berbahasa Indonesia, tim beralih ke proses penerjamahan dari bahasa asal ke bahasa Arab. Proses ini dilalui dengan cara menyusun kalimat hingga menjadi paragraf. Dibutuhkan penguasaan kata, grammatika (nahwu) dalam transkripsi ini. Hasil akhir dari penerjemahan adalah sebagai berikut:

$$
\begin{aligned}
& \text { PAGARALAM } \\
& \text { مدينة رائعة و باردة }
\end{aligned}
$$

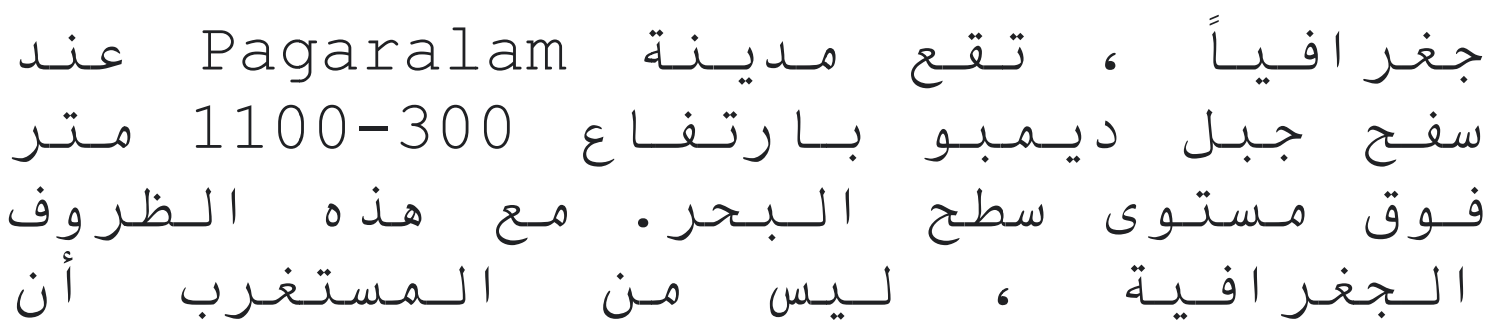




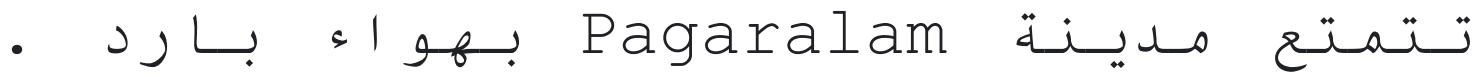

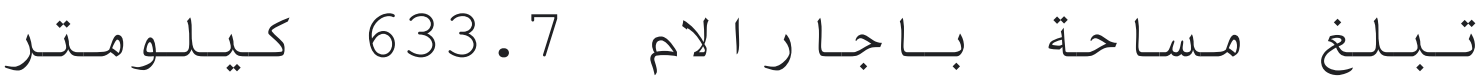

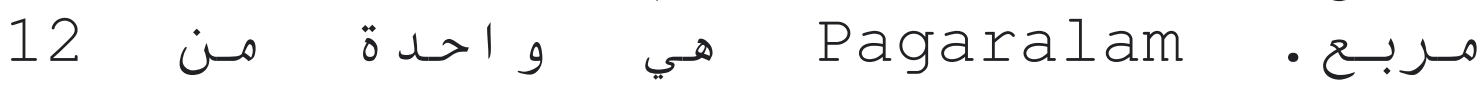

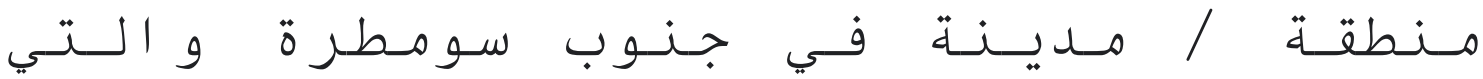

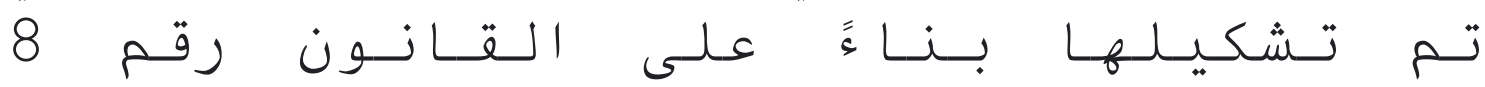

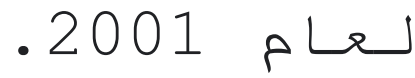

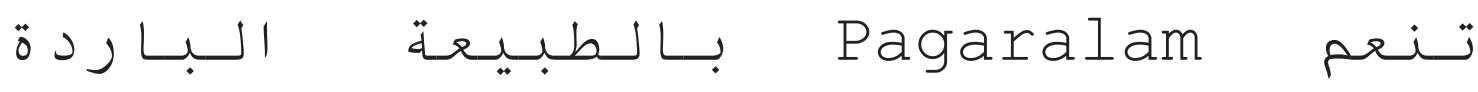

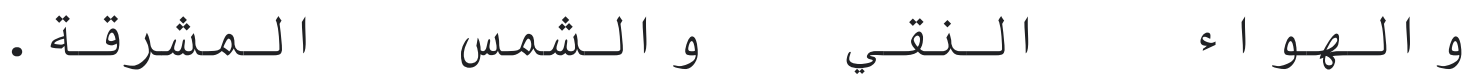

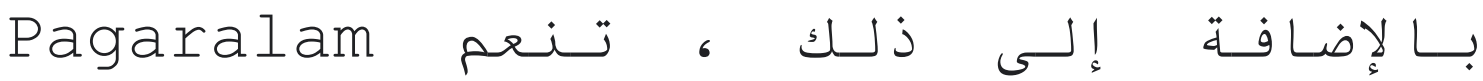

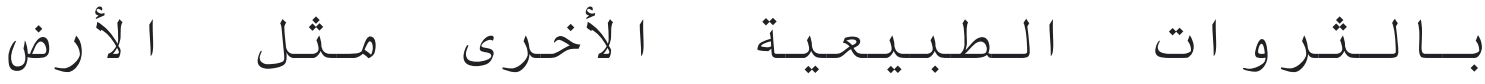

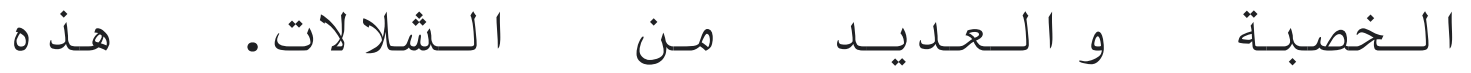

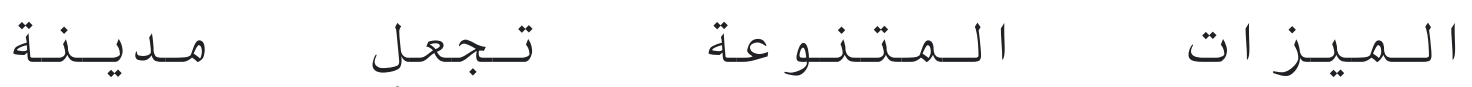

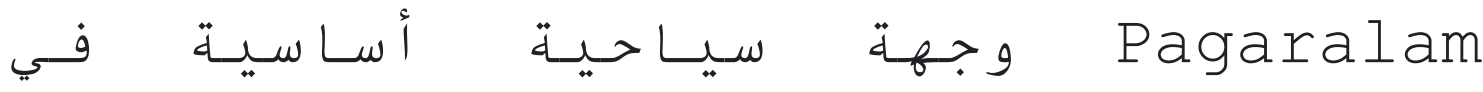
جــــوب سـومـطرة .

Pagaralam

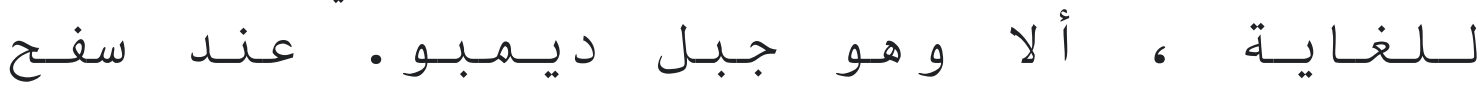

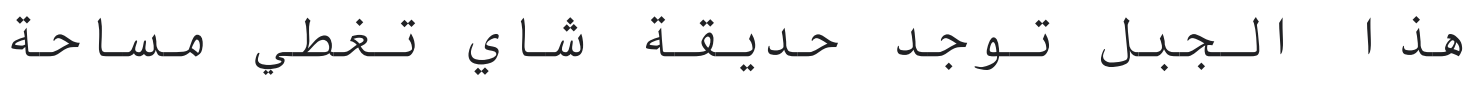

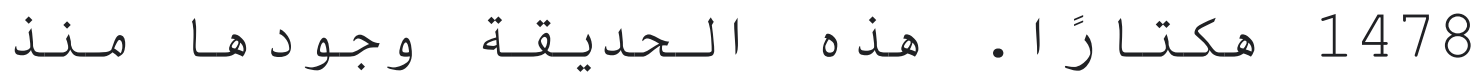

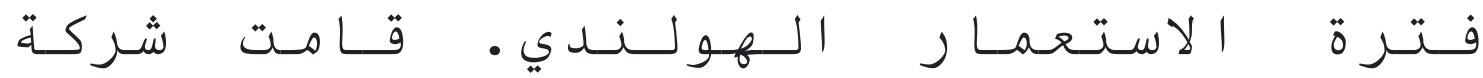

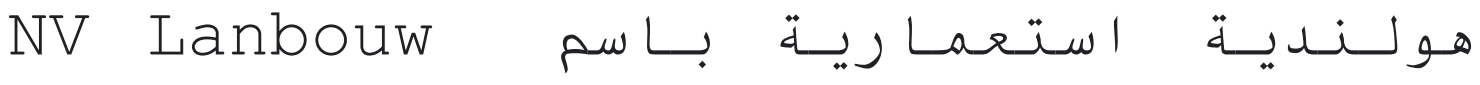

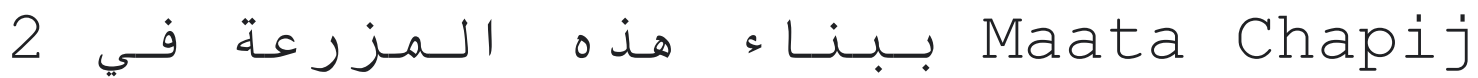

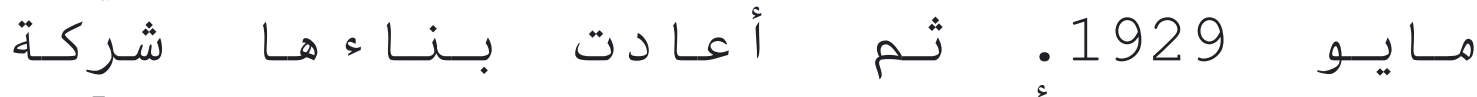

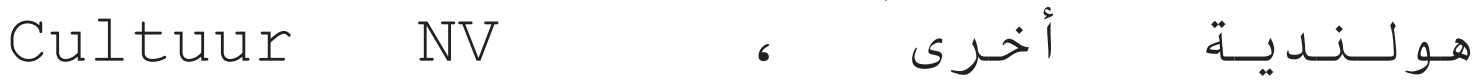
- Soerabaya في 1951-1958 


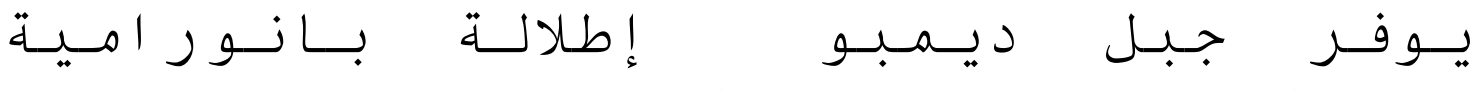

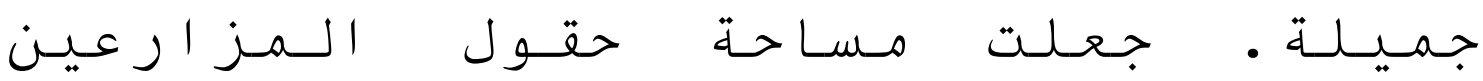

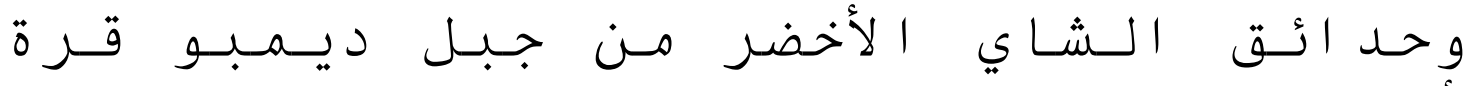

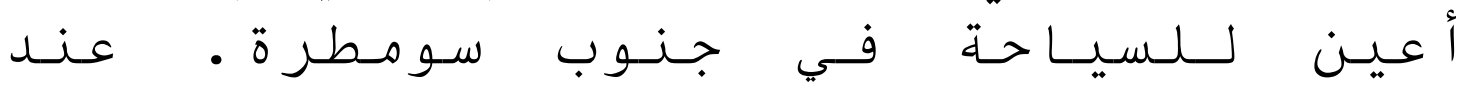

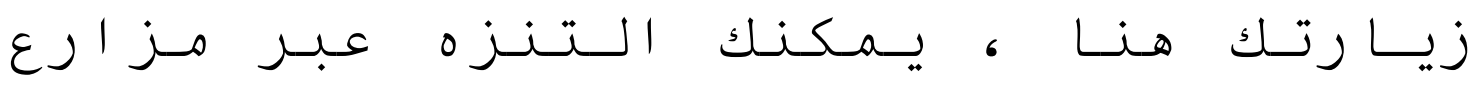

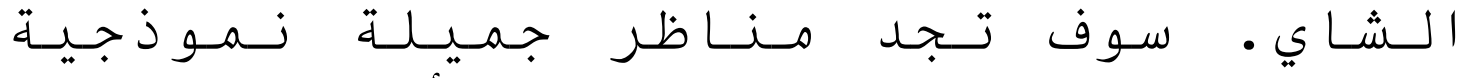

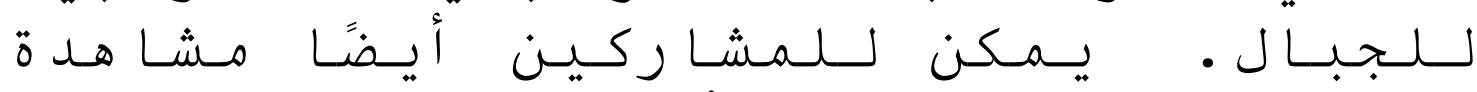

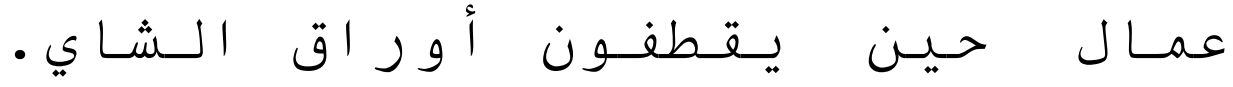

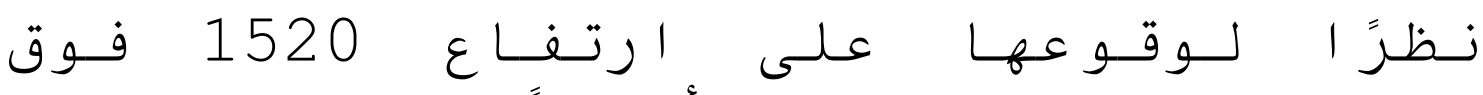

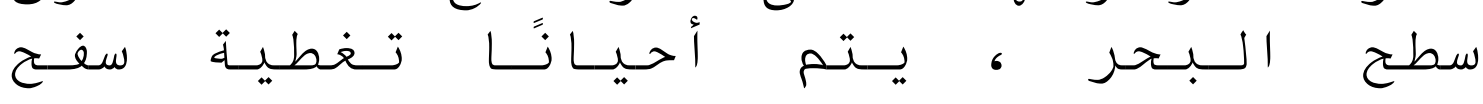

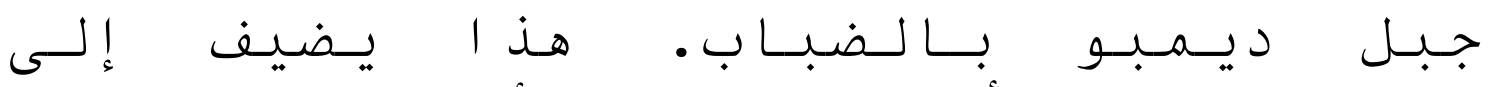

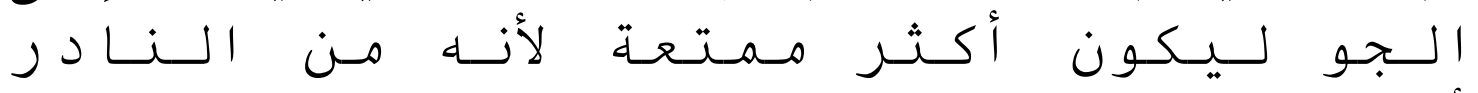

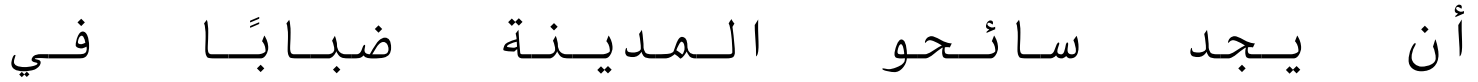

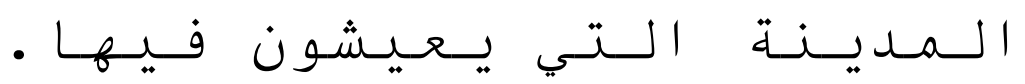

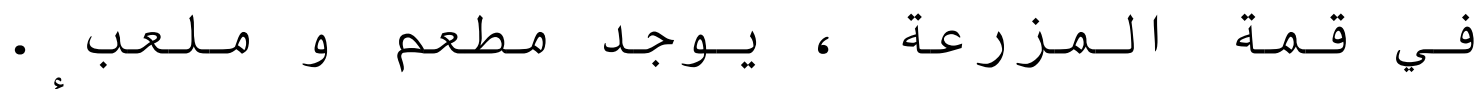

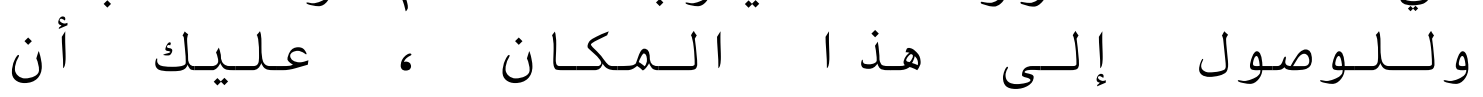

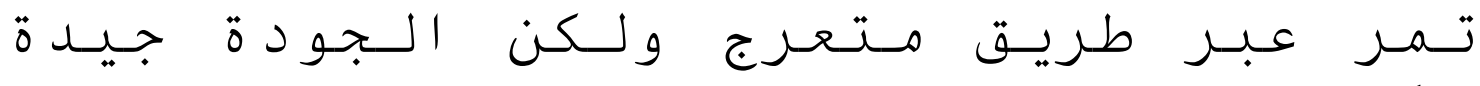

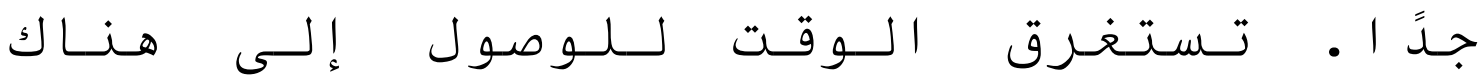
15

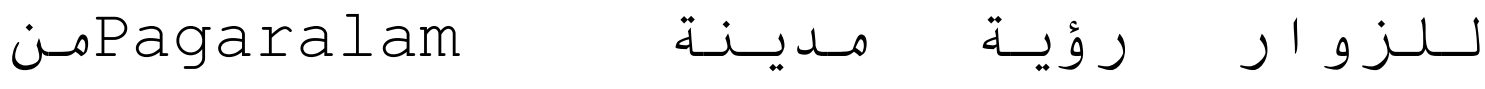

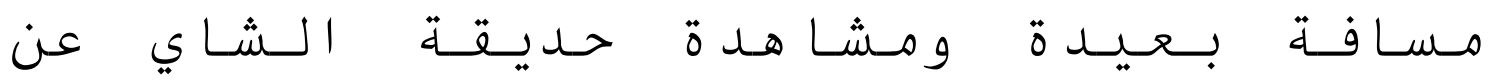

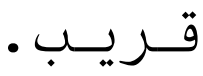

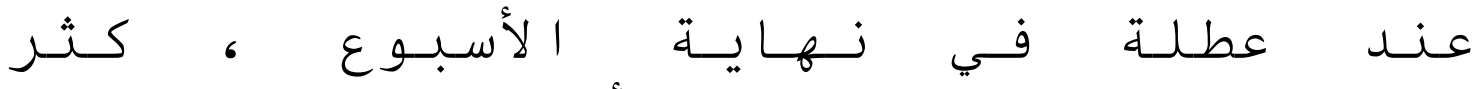

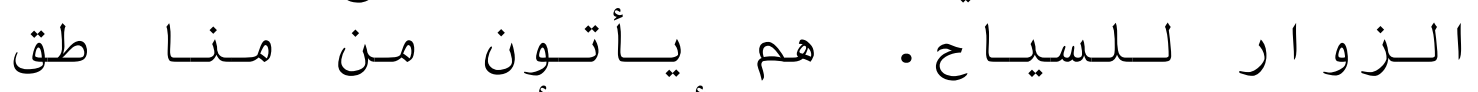

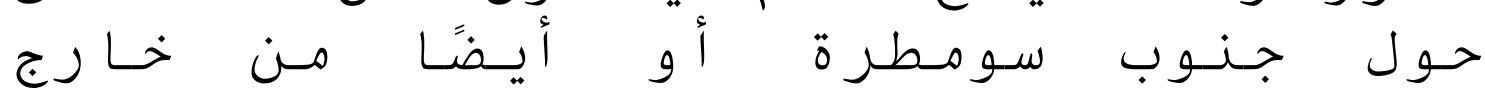




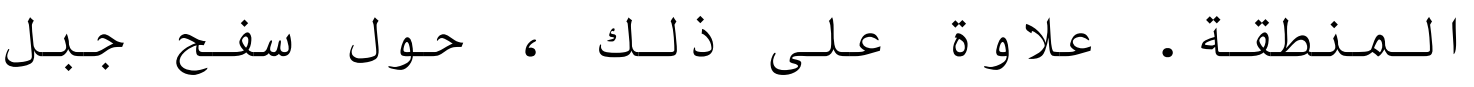

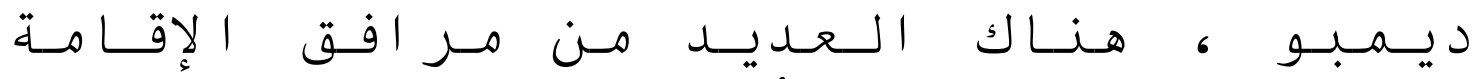

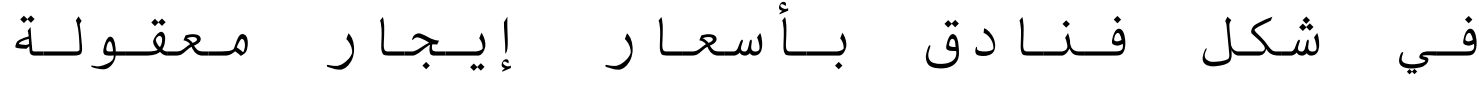

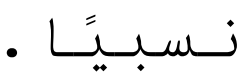

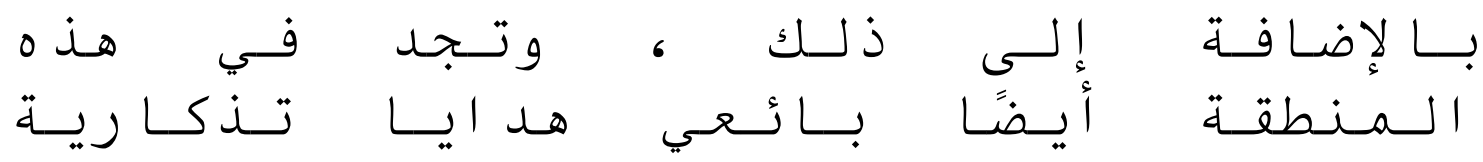

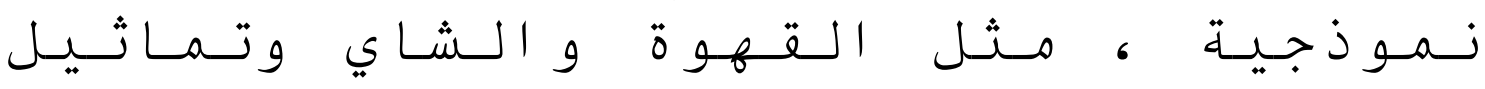

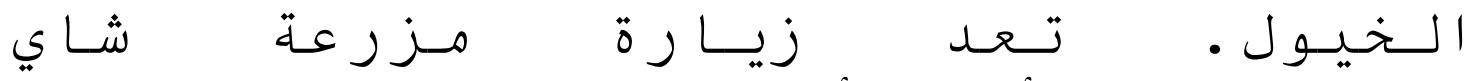

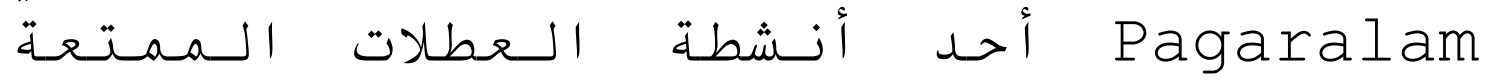

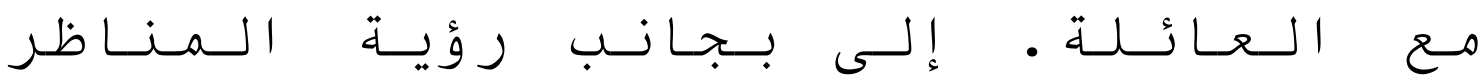

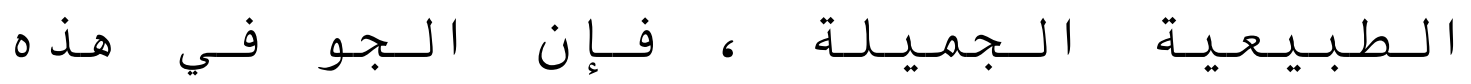

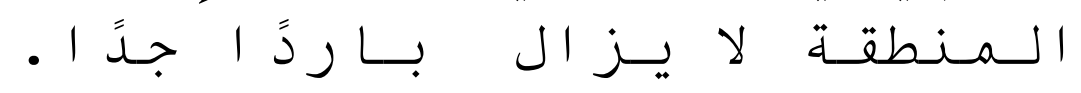

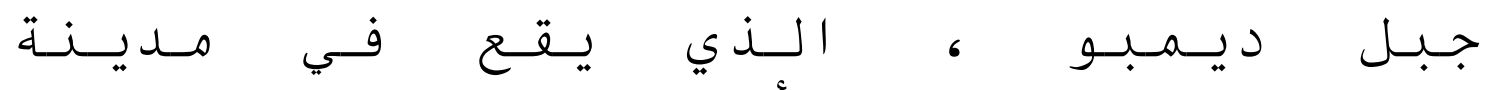

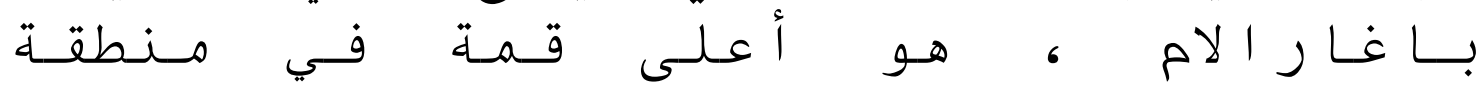

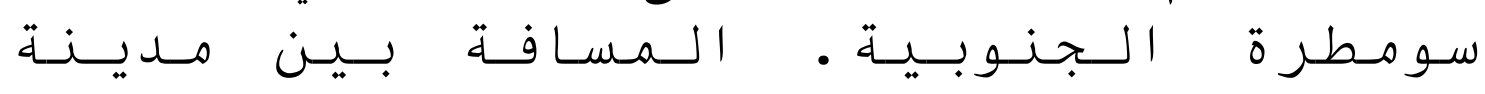
Pagaralam ، 300

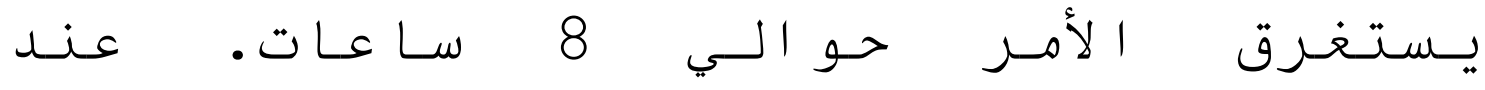

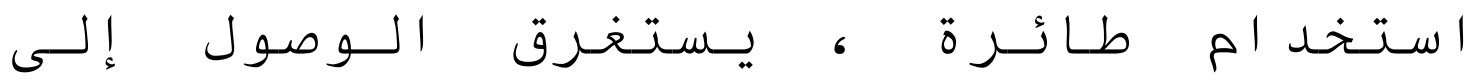

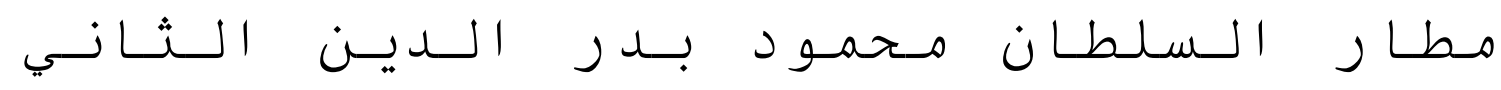

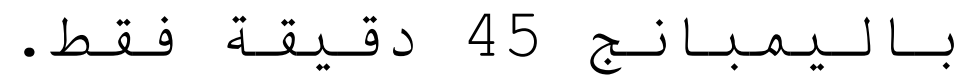

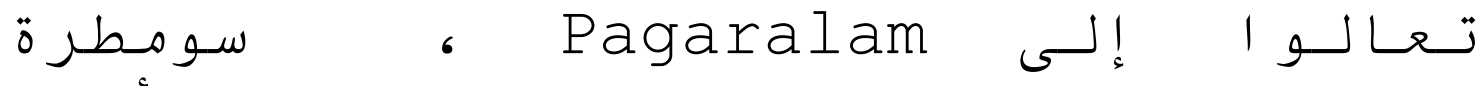

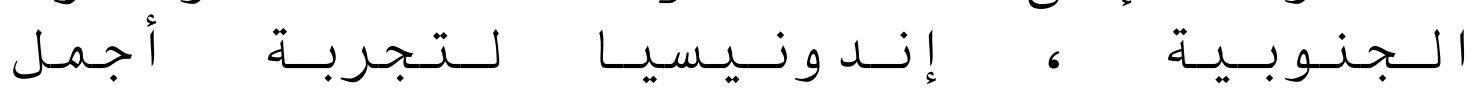
4. Proses Pengambilan Gambar

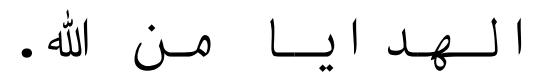


Pada keesokan harinya, tim kolaborasi berangkat menuju perkebunan teh di Utara kota Pagaralam. Kondisi alam yang sejuk dan keheningan musim pandemi memudahkan tim untuk melakukan pengambilan gambar kebun teh. Pengambilan gambar dengan alat yang sangat sederhana berupa android. Alat ini dipilih karena memang keterbatasan prasarana, namun demikian hasilnnya juga tidaklah mengecewakan. Gambar tadi direkam daam format video dan gambar statis yang kelak akan diolah pada proses editing.

5. Proses Editing

Proses editing dilakukan oleh salah satu anggota tim yang memiliki kecakapan di bidang IT. Aplikasi yang digunakan juga sengat sederhana dan sangat mudah dipelajari oleh para santriwati. Proses editing ini juga adalah proses alih teknologi dari mahasiswa BSA kepada santriwati Ponpes al-azhar. Tidak lupa pula, dalam proses editing ini adalah menambahkan tulisan, musik pengiring ke dalam video.

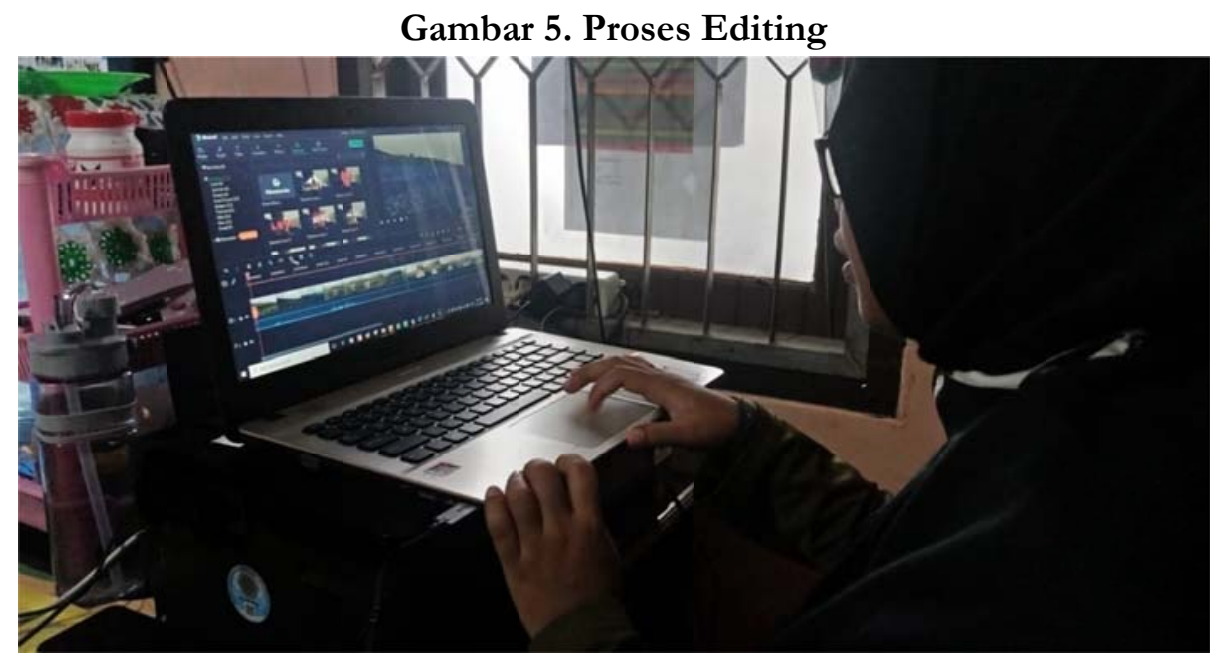

6. Proses uploading

Proses uploading adalah proses terakhir yang dilalui. Setelah semua video dianggap sempurna, maka video tersebut diupload ke dalam kanal youtube prodi BSA dengan nama kanal Channel Sastra dan kanal Youtube Ponpes Al-Azhar. Adapun tautannya dapat dilihat pada kanal berikut ini: https://youtu.be/3cTDjRBROK4.

\section{Gambar 6. Sebagian tampilan video di Youtube}



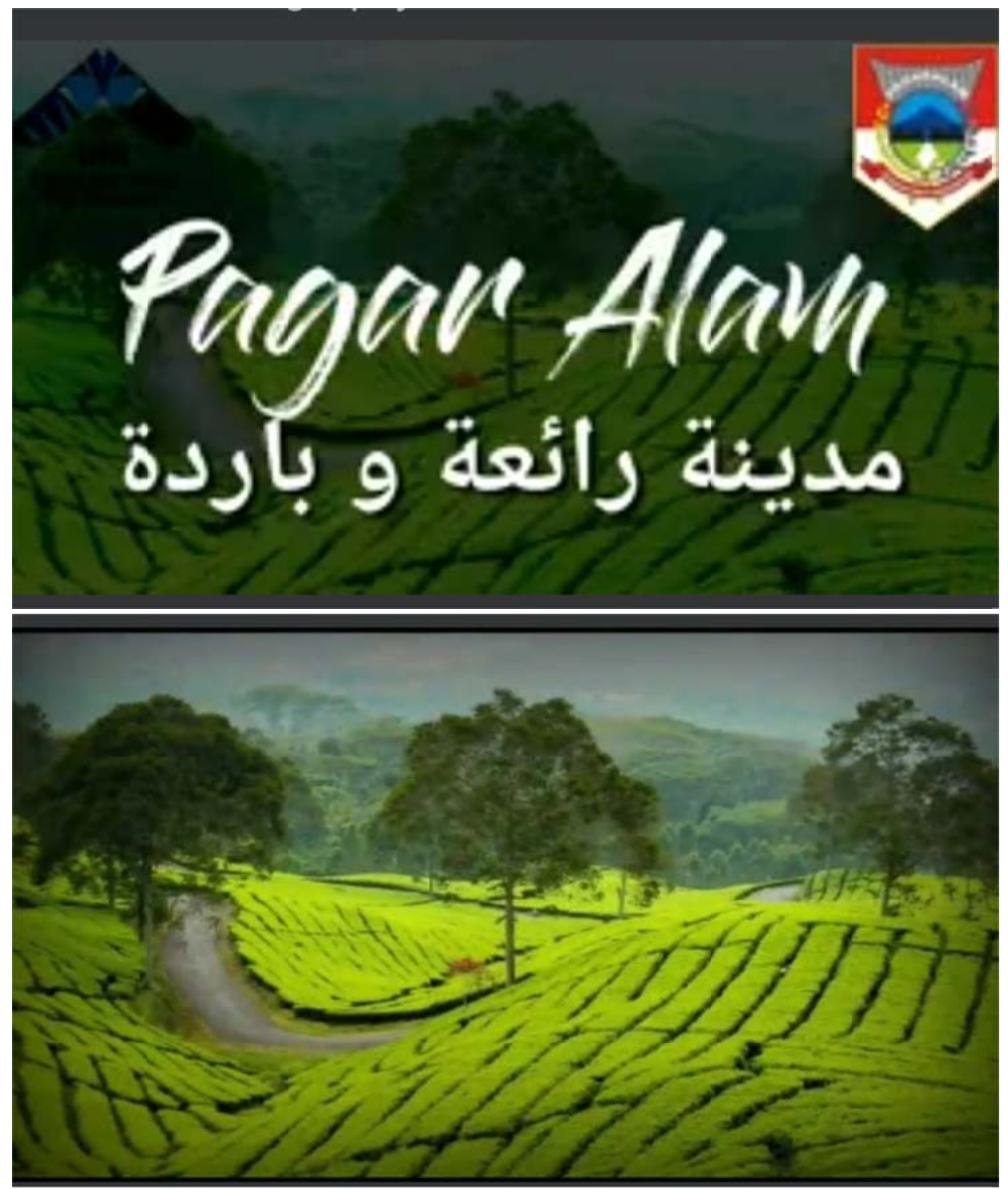

\section{Refleksi Capaian Program}

Media sosial (facebook, instagram, twitter, dan Youtube) saat ini merupakan bagian dari revolusi sistem pemasaran yang marak digunakan pada era disrupsi 0.4. Sistem pemasaran ini dipandang sebagai cara baru pemasaran yang progressif dan berbiaya murah. Hal ini sangat berbeda dengan sistem pemasaran konvensional yang berbiaya tinggi dengan memasang platform iklan di berbagai media cetak. Di samping itu, jangkauan pemasaran berbasis media sosial lebih mampu menjangkau calon wisatawan dari berbagai belahan dunia.

Dunia pariwisata sangat diuntungkan dengan adanya media baru ini. Pada saat ini, para millenial berbagai negara rela mengubah pola hidup mereka dari kemapanan menjadi petualangan. Artinya, mereka tidak lagi berfikir investasi secara konvesional, tetapi investasi berupa travelling mengelilingi dunia sebagai pilihan yang banyak dilakukan para millenial.

Menyambut perubahan paradigma ini, Indonesia dengan potensi kekayaan alamnya yang 
luar biasa tidak bisa berdiam diri. Indonesia harus menggandeng segala sumber daya manusianya untuk bahu membahu pemasaran pariwsisatanya.

Perguruan tinggi yang memiliki program studi bahasa asing sangat tepat mengambil peran ini sebagai bentuk kontribusinya dalam pengembangan pariwisata sekaligus ekonomi kreatif. Prodi BSA khususnya, bisa mengambil peran lebih jauh dengan memasarkan potensi pariwisata tersebut ke negara-negara Timur Tengah melalui media sosial.

Pengabdian kepada masyarakat dengan tema Pendampingan Pemasaran Potensi Wisata Pagaralam ke Wilayah Timur Tengah oleh Prodi BSA UIN Raden Fatah dengan cara menyusun rencana dan mengaplikasannya dalam bentuk video di saluran Youtube adalah sebuah usaha kecil untuk berkontribusi pada bangsa.

Hasil capaian ini tidak bisa langsung diukur dalam waktu yang singkat. Sebab penyebaran Youtube dan respon balik dari pemirsa tidaklah bisa langsung didokumentasikan. Hanya saja, berdasarkan keberhasilan media sosial lain dalam memeromosikan berbagai tempat pariwisata, biasanya sebuah tempat bisa menjadi viral dan mendadak dikunjungi banyak wisatawan hanya karena sebuah postingan di media sosial saja.

Khusus kasus video ini, peneliti akan terus mencermati berapa besar respon dan impact dari masyarakat pemerisa video ini yang tertarik dengan lokasi wisata ini.

\section{Penutup}

Kesimpulan terhadap pelaksanaan kegiatan $\mathrm{PkM}$ ini bisa diukur dari respon positif pemerintah kota Pagaralam terhadap rencana pelaksanaan $\mathrm{PkM}$ ini. Mereka memberikan kesempatan yang luas kepada tim $\mathrm{PkM}$ dari Prodi BSA untuk mengeksplorasi sumber daya alam dan manusia secara positif.

Respon SDM Pondok Pesantren al-Azhar juga menunjukkan aura positif dengan antusiasime santriwati ketika kuliah umum dan juga saat terbentuknya tim kecil untuk eksekusi penyusunan dan pembuatan video.

Setelah video diupload, harusnya dapat ditemukan respon pemirsa dalam kolom komentar. Namun karena kurangnya waktu, respon tersebut belum dapat dianalisis. Tim pengabdian yakin, bahwa pola pemasaran melalui media sosial ini masih akan tetapuptodate sebagai metode pemasaran di era disrupsi.

\section{Daftar Pustaka}

Ma'luf, Louis, Kamus al-Munjid fi al-Lughah wa al-A'lam, Darul Masyriq: Beirut

https://sippa.ciptakarya.pu.go.id/sippa online/ws file/dokumen/rpi2jm/DOCRPIJM 1503 134022Bab 4 Profil Kota PGA.pdf

https://www.tokopedia.com/blog/travel-objek-wisata-pagar-alam-terbaik/

https://www.andalastourism.com/tempat-wisata-pagar-alam 